Eksakta Vol. 18 No. 2, Oktober 2017

http://eksakta.ppj.unp.ac.id

E-ISSN : 2549-7464

P-ISSN : 1411-3724

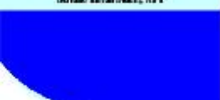

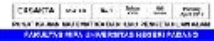

\title{
PEMANFAATAN AIR KELAPA UNTUK MENINGKATKAN PERTUMBUHAN AKAR STEK TUNAS AKSILAR Andrographis paniculata Nees
}

\author{
Retno Prihatini \\ Jurusan Biologi FMIPA Universitas Andalas \\ email : retnoprihatini@gmail.com
}

\begin{abstract}
The research has been conducted to find out the best concentration of coconut water in the induction of roots of cuttings axillary buds Andrographis paniculata Nees. This research was conducted in Plant Physilogy of Division, Department of Biology, Faculty of Math and Natural Science, AndalasUniversity, for 12 weeks. The research used Completely Randomized Design. The material used was axillary buds A. paniculata with nodal number 3 . treated for 30 minutes in coconut water 10, 15 and $20 \%$ and aquadest as a controle each with 6 replications. Observations were done on live percentage, root length, root numerous and cuttings height after 12 weeks planting. The results showed that the concentration 10 to $15 \%$ of coconut water was able with significant to induce the root growth of cutting axillary buds A. Paniculat. The concentration $15 \%$ of coconut water was the best in inducing cutting height growth, each with an average root length is $8.2 \mathrm{~cm}$ and the average number of roots that formed is 16, 0 and the average cutting height is $22.7 \mathrm{~cm}$. There was an increase of average of cuttings height growth by $86 \%$ which was supported by the average increase of root length and root number of $105.0 \%$ and $280.9 \%$ on the occasion of cuttings of axillary buds in coconut water concentration $15 \%$.
\end{abstract}

Keywords : Andrographis paniculata, root induction, aksilar shoots cuttings, coconut water

\section{PENDAHULUAN}

Andrographis paniculata Nees adalah tanaman herba yang tumbuh menyebar di Asia Tenggara, India, dan Cina. Di Indonesia dan Malaysia, tanaman ini telah digunakan secara ekstensif sebagai obat tradisional dalam mengobati demam, disentri, diare, inflamasi dan radang tenggorokan (Kumoro et al., 2009). Senyawa-senyawa aktif yang dikandung A. paniculata, sebenarnya adalah metabolit sekunder yang antara lain termasuk ke dalam golongan diterpen, contohnya: andrographolid, neoandrographolid dan dehidro-andrographolid.

Di Indonesia, sambiloto termasuk dalam kategori tanaman obat budidaya yang diusahakan dalam skala sempit dengan prioritas penelitian adalah mencari varietas unggul dan pengembangan teknik budidaya (Pribadi, 2009). Tanaman obat sambiloto ini dapat dibudidaya dengan biji dan juga stek batang.

Perbanyakan dengan stek merupakan perbanyakan vegetatif konvensional, dengan menggunakan bahan berupa batang, tunas pucuk 
maupun tunas ketiak daun (tunas aksilar). Keuntungan yang diperoleh dengan stek tunas adalah tanaman mempunyai keunggulan sifat sifat yang sama dengan tanaman induk, jika tanaman induk adalah tanaman dewasa yang rimbun, banyak cabangnya, maka dari satu tanaman induk bisa dihasilkan banyak materi stek. Stek akan mampu tumbuh dengan baik jika disokong oleh sistem perakaran yang baik pula. Hal ini sesuai dengan fungsi dari akar yaitu menyerap air dan hara untuk dikirim keseluruh tubuh tanaman.

Kemampuan stek membentuk akar dipengaruhi oleh zat pengatur tumbuh alami pada tanaman (fitohormon), maupun zat pengatur tumbuh yang diberikan secara eksogen. Air kelapa adalah salah satu contoh bahan yang sudah lama dimanfaatkan orang dalam pertanian, yaitu terutama untuk menginduksi pertumbuhan akar maupun pertumbuhan tanaman secara keseluruhan. Pada tanaman jati pemberian air kelapa konsentrasi 50$100 \%$ dapat meningkatkan pertumbuhan stek batang jati (Renvillia dkk. 2016). Pada Veitchia merillii pemberian air kelapa konsentrasi 25-50\% meningkatkan panjang akar 0,04- $0,12 \mathrm{~cm} /$ hari ( Sujarwati dkk., 2011)

Dalam riset ini potensi air kelapa dalam induksi akar dijadikan kajian utama investigasi. Riset ini dilakukan dengan menginduksi akar dari stek tunas aksilar Andrographis paniculata yang direndam dalam beberapa konsentrasi air kelapa. Dalam penelitian ini, ditelaah konsentrasi air kelapa yang paling baik dalam menginduksi pertumbuhan akar $A$. Paniculata.
STUDI PUSTAKA

2.1Andrographis paniculata Nees

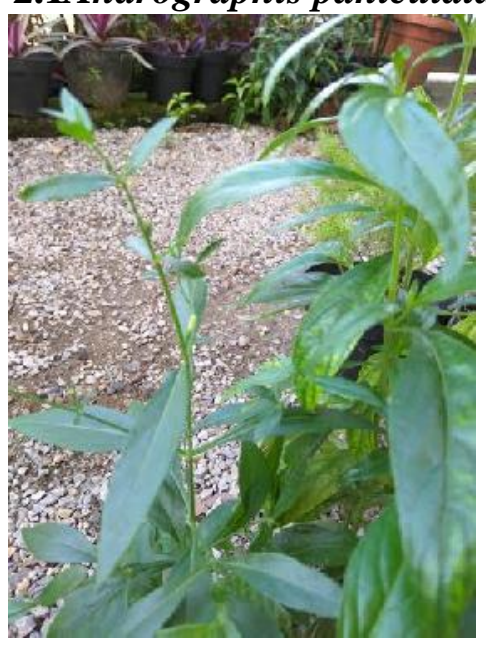

Gambar 1. Andrographis paniculata Nees Tanaman ini termasuk kedalam familia Acanthaceae. Tanaman Andrographis paniculata Nees, adalah herba yang mempunyai deskripsi botani sbb. tinggi $30-110 \mathrm{~cm}$, batang disertai banyak cabang, berbentuk segi empat (kwadrangularis), tekstur batang mudah patah, . Daun sederhana/ tunggal, bertangkai pendek, letak berhadapan bersilang, bentuk lanset, pangkal runcing, ujung meruncing, panjang $2-12 \mathrm{~cm}$, lebar 1 - $3 \mathrm{~cm}$. Bunga inflorescence terdapat pada bagian terminal dan axial panicula pangjang $10-30 \mathrm{~mm}$, braktea kecil, , pedicel pendek, calyx terdiri dari 5 bagian, kecil linear, corolla berbentuk tabung, panjang $6 \mathrm{~mm}$ dengan limb lebih panjang dari tabung, bilabiate, warnanya putih bernoda ungu. Buah kapsul berbentuk jorong, panjang sekitar 1-2 cm, lebar 2-5 mm, dengan rambut kelenjar. Biji sangat kecil, sub kuadrate. (Mishra et al., 2007)

Perbanyakan vegetative Andrographis paniculata dapat dapat dilakukan antaralain adalah dengan stek, yaitu pemotongan atau pemisahan bagian tubuh tanaman, agar bagian tersebut dapat membentuk akar dan menjadi individu baru . Dengan cara stek diharapkan dapat 


\section{Eksakta Vol. 18 No. 2 Oktober 2017}

E-ISSN : 2549-7464, P-ISSN : 1411-3724

menghasilkan generasi mempunyai sifat keunggulan yang sama dengan tanaman induknya. Jika tanaman induk adalah tanaman dewasa yang rimbun, banyak cabangnya, maka dari satu tanaman induk bisa dihasilkan banyak materi stek.

2.2. Penggunaan air kelapa untuk pertumbuhan akar bibit atau seedling.

Air kelapa mampu menginduksi maupun mempercepat pertumbuhan akar tanaman. Hal ini karena ia mengandung berbagai mineral dan fitohormon diantaranya yang paling utama adalah kelompok auksin, diikuti kelompok sitokinin, giberelin dan asam absisat. Berikut ini adalah Tabel yang menunjukkan estimasi konsentrasi fitohormon dari air kelapa.

Tabel 1. Fitohormon alami yang terdapat pada air kelapa

\begin{tabular}{|c|c|c|}
\hline \multicolumn{2}{|c|}{ Jenis Fitohormon/Zat Pengatur Tumbuh } & \multirow{2}{*}{$\begin{array}{c}\text { Estimasi konsentrasi } \\
(\mathrm{x} 10-3 \mu \mathrm{M})\end{array}$} \\
\hline Sitokinin & Isopentenil adenin & \\
\hline & dihidrozeatin & 0,14 \\
\hline & Trans-zeatin & 0,09 \\
\hline & kinetin & 0,31 \\
\hline & Ortho-topolin & 3,29 \\
\hline & Dihidrozeatin O- glukosida & 46,6 \\
\hline & Trans-zeatin O- gluksida & 48,7 \\
\hline & Trans-zeatin ribosida & 76,2 \\
\hline & Kinetin ribosida & 0,33 \\
\hline & $\begin{array}{llll}\begin{array}{l}\text { Trans-zeatin ribosida } \\
\text { posfat }\end{array} & & \text { mono } \\
\end{array}$ & 10,2 \\
\hline & 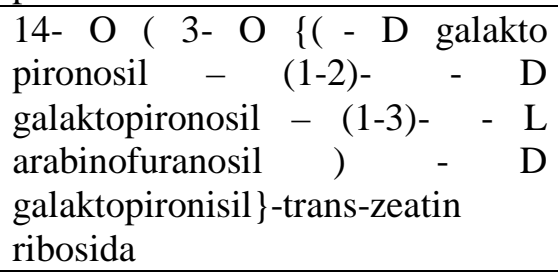 & Ada \\
\hline \multirow[t]{2}{*}{ Giberelin } & Giberelin 1 & 16,7 \\
\hline & Giberelin 3 & 37,8 \\
\hline Auksin & Indole-3-Acetic Acid & 150,6 \\
\hline Asam Absisat & Absisic acid & 65,5 \\
\hline
\end{tabular}

(Sumber. Yong et al., 2011).

Fitohormon maupun zat pengatur tumbuh mempunyai peranan dalam pertumbuhan dan perkembangan tanaman untuk kelangsungan hidupnya. Menurut Khrisnamoorthy (1981), proses tumbuh pada tanaman meliputi perbesaran sel, pembelahan sel, serta differensiasi. Pertumbuhan dan perkembangan diatur oleh zat-zat kimia yang disebut zat pengatur tumbuh.

Zat pengatur tumbuh ini dibagi dalam lima kelompok utama yaitu : auksin, sitokinin, giberellin,absisi dan etilen.. Menurut Bhojwani dan Razdan (1983) auksin mempengaruhi pembelahan sel dan pembentukan akar. Auksin ada 2 macam yaitu auksin alami, contohnya 
E-ISSN : 2549-7464, P-ISSN : 1411-3724

IAA (Asam $\beta$-indol acetic) dan auksin sintetik yang sering digunakan yaitu NAA (Asam $\alpha$-Naphtalen acetic). Auksin sintetik cenderung lebih aktif dibandingkan auksin alami. Kelebihannya yaitu tidak mudah terdegradasi oleh enzim yang dihasilkan sel jaringan dan tanaman. NAA merupakan auksin yang sangat efektif untuk menginduksi akar dan disebut sebagai "auksin sintetis kuat" (George dan Sherrington, 1984). Auksin golongan IAA adalah auksin yang dapat mendorong pertumbuhan jaringan dalam waktu cepat, tapi auksin ini tidak stabil.

\section{METODE PENELITIAN}

Penelitian dilakukan dengan menggunakan Rancangan Acak Lengkap (RAL) . Perlakuan berupa perendaman tunas aksilar A.paniculata selama 30 menit dalam larutan, antara lain Akuades (Kontrol) ; Air kelapa 10\% ; Air kelapa $15 \%$ dan Air kelapa $20 \%$. Masing masing perlakuan dengan 6 ulangan. Penelitian ini dilaksanakan Juli 2015 di Jurusan Biologi, Fakultas Matematika dan Ilmu Pengetahuan Alam, Universitas Andalas

Bahan yang digunakan adalah tunas aksilar A. paniculata dengan jumlah nodus 3 dari tanaman berumur 60 hari. Air kelapa konsentrasi 10, 15, dan 20\%, akuades, media tanam berupa tanah kebun : pasir $1: 2$. Alat yang digunakan yaitu pelastik cup , penggaris, ember, timbangan, alat tulis, pisau, label, kamera digital.

\section{Prosedur Kerja}

Tunas aksilar A. paniculata dengan jumlah nodus 3 , direndam dalam larutan air kelapa, masing-masing dengan konsentrasi 1;2 ppm, dan direndam dengan akuades sebagai kontrol, kemudian ditanam dalam pelastik cup berisi media tanam dengan komposisi tanah kebun:pasir (1:2). Selanjutnya tanaman ditempatkandi rumah kawat, serta kelembaban udara dijaga di atas $70 \%$, dengan cara menyungkup tanaman dengan pelastik yang disemprot dengan air . Penyiraman tanaman dilakukan setiap 2 hari .

\section{Parameter Pengamatan}

Parameter pengamatan meliputi : Persentase hidup setelah 12 minggu penanaman; Panjang dan jumlah akar setelah 4 minggu penanaman; tinggi tanaman setelah 12 minggu penanaman.

Persentase Hidup $=\left(\sum\right.$ stek tunas aksilar yang hidup/ ulangan) x 100\%

\section{Analisis Data}

Analisis data dilakukan terhadap panjang akar, tinggi tunas dengan menggunakan uji $\mathrm{F}$ pada taraf nyata $5 \%$ dan disajikan dalam bentuk tabel. Jika $\mathrm{F}$ hit $>$ dari $\mathrm{F}$ tab dilanjutkan dengan uji DNMRT pada taraf 5\%.

\section{HASIL DAN PEMBAHASAN}

Induksi akar pada stek tunas aksilar A. Paniculata dengan menggunakan air kelapa 10, 15 dan 20\% dan akuades sebagai kontrol menunjukkan respons tumbuh berupa persentase hidup, panjang dan jumlah akar serta tinggi tanaman setelah 12 minggu penanaman, terlihat pada Tabel 2 dan Gambar 2. 


\section{Eksakta Vol. 18 No. 2 Oktober $\mid 2017$}

E-ISSN : 2549-7464, P-ISSN : 1411-3724

Tabel 2. Respons tumbuh stek tunas aksilar A. Paniculata terhadap induksi akar dengan air kelapa setelah 12 minggu penanaman.

\begin{tabular}{|l|l|c|c|c|c|}
\hline $\begin{array}{c}\text { Kode } \\
\text { Perlakuan }\end{array}$ & \multicolumn{1}{|c|}{ Perlakuan } & $\begin{array}{c}\text { Persentase } \\
\text { hidup (\%) }\end{array}$ & $\begin{array}{c}\text { Rata-rata } \\
\text { Panjang akar } \\
(\mathrm{cm})\end{array}$ & $\begin{array}{c}\text { Rata-rata } \\
\text { jumlah } \\
\text { akar }\end{array}$ & $\begin{array}{c}\text { Rata-rata } \\
\text { tinggi stek } \\
\text { tunas aksilar } \\
(\mathrm{cm})\end{array}$ \\
\hline A & Aquadest (kontrol) & 100 & $4,0 \mathrm{c}$ & $4,2 \mathrm{c}$ & $12,2 \mathrm{c}$ \\
\hline B & Air Kelapa 10\% & 100 & $6,2 \mathrm{~b}$ & $9,4 \mathrm{~b}$ & $18,2 \mathrm{~b}$ \\
\hline C & Air Kelapa 15\% & 100 & $8,2 \mathrm{a}$ & $16,0 \mathrm{a}$ & $22,7 \mathrm{a}$ \\
\hline D & Air Kelapa 20\% & 100 & $4,2 \mathrm{c}$ & $4,0 \mathrm{c}$ & $12,8 \mathrm{c}$ \\
\hline
\end{tabular}

Keterangan : angka yang diikuti huruf yang berbeda pada kolom yang sama menunjukkan perbedaan yang nyata pada selang kepercayaan 95\%

Respons tumbuh dengan persentase hidup tinggi $(100 \%)$ pada keseluruhan perlakuan menunjukkan bahwa, kemampuan stek aksilar A. Paniculata untuk hidup tinggi, hal ini didukung oleh kondisi lingkungan yang cocok, yaitu kelembaban udara (RH> 70\%). serta sumber bahan stek yang sehat. Dari hasil pengamatan terlihat bahwa perendaman stek tunas aksilar dalam air kelapa 10 hingga $15 \%$ mampu menginduksi secara nyata panjang akar, jumlah akar dan tinggi stek tunas aksilar A. Paniculata, (Tabel 2 dan Gambar 2.).

Perlakuan perendaman stek tunas aksilar A. paniculata dalam air kelapa konsentrasi $15 \%$ adalah terbaik dalam menginduksi akar dan menyokong pertumbuhan tinggi stek tunas aksilar , masing-masing dengan rata-rata panjang akar $8,2 \mathrm{~cm}$ dan rata-rata jumlah akar 16,0 serta tinggi stek tunas aksilar adalah $27,0 \mathrm{~cm}$ (Tabel 2). Menurut Bhojwani dan Razdan, (1983).ratio perbandingan auksin dan sitokinin menentukan arah pertumbuhan dan perkembangan jaringan tanaman. Dimana ratio auksin lebih tinggi dibandingkan sitokinin menyebabkan terinduksinya pembentukan akar serta pertumbuhan akar tanaman. Hal ini disokong oleh Yong et al., (2011), yang mengemukakan bahwa dari komposisi zat pengatur tumbuh yang terdapat pada air kelapa, ternyata Indole- 3 -acetic acid yang termasuk kelompok auksin adalah konsentrasi yang tertinggi, yaitu sebesar 150,6 $\mathrm{x} \quad 10^{-3} \mu \mathrm{M}$. Auksin juga mempengaruhi pembelahan sel dan pembentukan akar (Bhojwani dan Razdan, 1983). Pengaruh auksin terhadap pertumbuhan jaringan melalui 2 cara yaitu : 1). Menginduksi ion $\mathrm{H}^{+}$ keluar melalui dinding sel, dengan ini dinding sel menjadi asam mengakibatkan ion $\mathrm{K}^{+}$diikat dan seterusnya akan mengurangi potensial air dalam sel, sehingga air akan memasuki sel, dan sel akan menjadi besar. 2). Mempengaruhi metabolisme RNA yang berhubungan dengan metabolisme protein Krishnamoorthy (1981). 
E-ISSN : 2549-7464, P-ISSN : 1411-3724

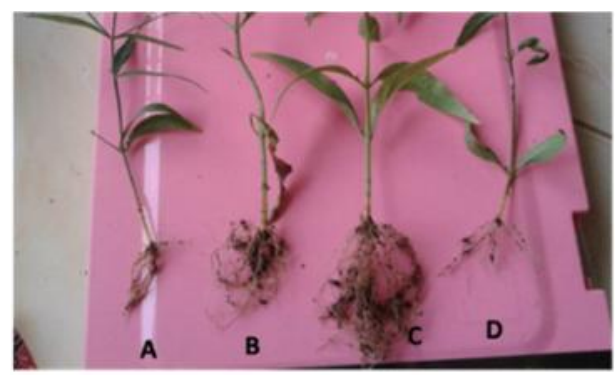

Gambar.2. Hasil Induksi akar pada Stek tunas aksilar A. Paniculata dengan perlakuan berupa perendaman tunas aksilar A.paniculata selama 30 menit dalam larutan sbb. A. Akuades (Kontrol) B. Air kelapa $10 \%$ C. Air kelapa $15 \%$ D. Air kelapa $20 \%$

Dari Tabel 2 juga terlihat bahwa perendaman stek tunas aksilar dalam air kelapa konsentrasi 10 hingga $20 \%$ mampu meningkatkan rata-rata tinggi stek tunas aksilar. Perendaman dengan konsentrasi $15 \%$ air kelapa menunjukkan pertumbuhan tunas aksilar terbaik yaitu dengan rata-rata tinggi tunas aksilar sebesar 22,7 cm. Atau dengan perkataan lain dapat dijelaskan bahwa, telah terjadi peningkatan rata-rata tinggi stek tunas aksilar sebesar $86 \%$ yang didukung oleh kenaikan rata-rata panjang akar dan jumlah akar sebesar 105,0\% dan 280,9\% pada perandaman stek tunas aksilar dalam konsentrasi air kelapa 15\%. Sementara pada penelitian lain yang dilakukan oleh Djamhuri, (2011), bahwa perendaman stek pucuk meranti tembaga (Shorea leprosula) selama 5 jam dengan air kelapa mampu meningkatkan persentase stek berakar sebesar $33 \%$.

\section{KESIMPULAN}

1. Air kelapa berpotensi dalam menginduksi pertumbuhan akar $A$. paniculata, dimana konsentrasi 10 hingga $15 \%$ air kelapa berpengaruh nyata terhadap jumlah akar dan panjang akar.
2. Konsentrasi $15 \%$ air kelapa merupakan konsentrasi terbaik dalam menginduksi pertumbuhan akar dan menyokong pertumbuhan tinggi stek tunas aksilar, masingmasing dengan rata-rata panjang akar sebesar $8,2 \mathrm{~cm}$ dan rata-rata jumlah akar yang terbentuk 16,0, serta tinggi stek tunas aksilar 22,7 $\mathrm{cm}$.

3. Perandaman stek tunas aksilar A. paniculata dalam konsentrasi air kelapa 15\%.mampu meningkatan rata-rata tinggi stek tunas aksilar sebesar 86\% yang didukung oleh kenaikan rata-rata panjang akar dan jumlaah akar sebesar 105,0\% dan $280,9 \%$.

\section{DAFTAR PUSTAKA}

Bhojwani, S.S. and M.K. Razdan. (1983).

Plant Tissue Culture Theory and Practice.

Elsevier. Amsterdam

Djamhuri, E. (2011). Pemanfaatan Air

Kelapa untuk Meningkatkan

Pertumbuhan Stek

Pucuk Meranti Tembaga (Shorea

leprosula Miq.) .JURNAL

SILVIKULTUR

TROPIKAVol. 02 No. 01 April

2011, Hal. 5 - 8 ISSN: 2086-8227

Krishnamoorthy, H.N. (1981). Plant

Growth Substance Tamo Graw.

Hill Publishing Company, New Delhi.

Kumoro A.C., Hasan, M. And Singh H. (2009). Effects of Solvent Properties on the

Soxhlet Extraction of Diterpenoid Lactons from Andrographis paniculata.

Science Asia 35(2009):306-309 


\section{http://citeseerx.ist.psu.edu/viewdoc/ \\ download}

Mishra S.K., Sangwan, N.S and Sangwan R.S. (2007). Phcog Rev. : Plant Review Andrographis (Kalmegh): Pharmacognosy Reviews Vol 1, Issue 2, Jul-Dec . Available on line : http://www.phcogrev.com

Pribadi, E.R. (2007) Kajian Kelayakan Usahatani Pola Tanam Sambiloto dengan Jagung. Jurnal Litri 13 (3), September 2007: 98-105. ISSN 0853-8212

Renvillia, R., Bintoro A., Riniarti, M. (2016). Penggunaan Air Kelapa untuk Stek Batang Jati (Tectona grandis). Jurnal Silva Lestari. Vol. 4 No. 1, Januari 2016

(61-68). ISSN 2339-0913 http://download.portalgaruda.org/ar ticle.php/

Sujarwati, Fathonah, S., Johano, E., dan Herlina. (2011). Penggunaan Air Kelapa untuk Meningkatkan Perkecambahan dan Pertumbuhan Palem Putri (Veitchia merillii). SAGU, Maret 2011. Vol. 10 No. 1 : 24-24 ISSN 1412-442

ttps://ejournal.unri.ac.id/index.php/ JSG/article/view/631

Yong, J.W.H., Ge, L., and Tan, S.W. (2011) Coconut Water .Poster on Conference of Chicago July 2011 